\title{
Synthesis of 2-substituted tryptophans via a C3- to C2-alkyl migration
}

\author{
Michele Mari, Simone Lucarini, Francesca Bartoccini, Giovanni Piersanti ${ }^{\star} \S$ \\ and Gilberto Spadoni
}

\author{
Full Research Paper \\ Address: \\ Department of Biomolecular Sciences, University of Urbino "Carlo \\ Bo", Piazza del Rinascimento 6, 61029 Urbino (PU), Italy \\ Email: \\ Giovanni Piersanti* - giovanni.piersanti@uniurb.it \\ * Corresponding author \\ § Phone, +390722303320; Fax, +390722303313 \\ Keywords: \\ Dehydroalanine; Friedel-Crafts alkylation; indoles; migration; \\ tryptophans
}

Beilstein J. Org. Chem. 2014, 10, 1991-1998. doi:10.3762/bjoc. 10.207

Received: 30 May 2014

Accepted: 08 August 2014

Published: 26 August 2014

Associate Editor: B. Stoltz

(C) 2014 Mari et al; licensee Beilstein-Institut. License and terms: see end of document.

\begin{abstract}
The reaction of 3-substituted indoles with dehydroalanine (Dha) derivatives under Lewis acid-mediated conditions has been investigated. The formation of 2-substituted tryptophans is proposed to occur through a selective alkylative dearomatization-cyclization followed by $\mathrm{C} 3$ - to $\mathrm{C} 2$-alkyl migration and rearomatization.
\end{abstract}

\section{Introduction}

Facile access to tryptophan and unnatural tryptophan derivatives is of general interest because tryptophans are found in many naturally occurring compounds and are an important component of biologically active compounds [1-7]. Tryptophan and tryptophan analogs also have applications in chemical biology thanks to the highly environment-sensitive fluorescence properties of the indole ring [8-17] and when incorporated into peptides, they lead to compounds with increased resistance to enzymatic degradation and modification [18-25].

As part of our ongoing research on the use of the unsaturated amino acid dehydroalanine (Dha) in organic synthesis [26-37], we have focused our attention on the syntheses of tryptophans, cyclo-tryptophans (also known as pyrroloindolines), and trypto- phan-containing natural products from simple indole starting materials [38-44].

In 2010, we reported a novel one-pot approach for the preparation of pyrroloindolines 4 by a cascade addition/cyclization strategy between simple alkyl C3-substituted indoles $\mathbf{1}$ and 2-amidoacrylates $\mathbf{2}$ in the presence of stoichiometric amounts of a hard Lewis acid (Scheme 1, path a) [39]. Good yields and high exo:endo diastereoselectivities were obtained for a variety of indoles.

If the reaction is performed with indoles containing groups with good migratory aptitude at the $\mathrm{C} 3$ position, a mixture of the expected pyrroloindoline $\mathbf{4}$ and 2 -substituted tryptophans $\mathbf{3}$ was 


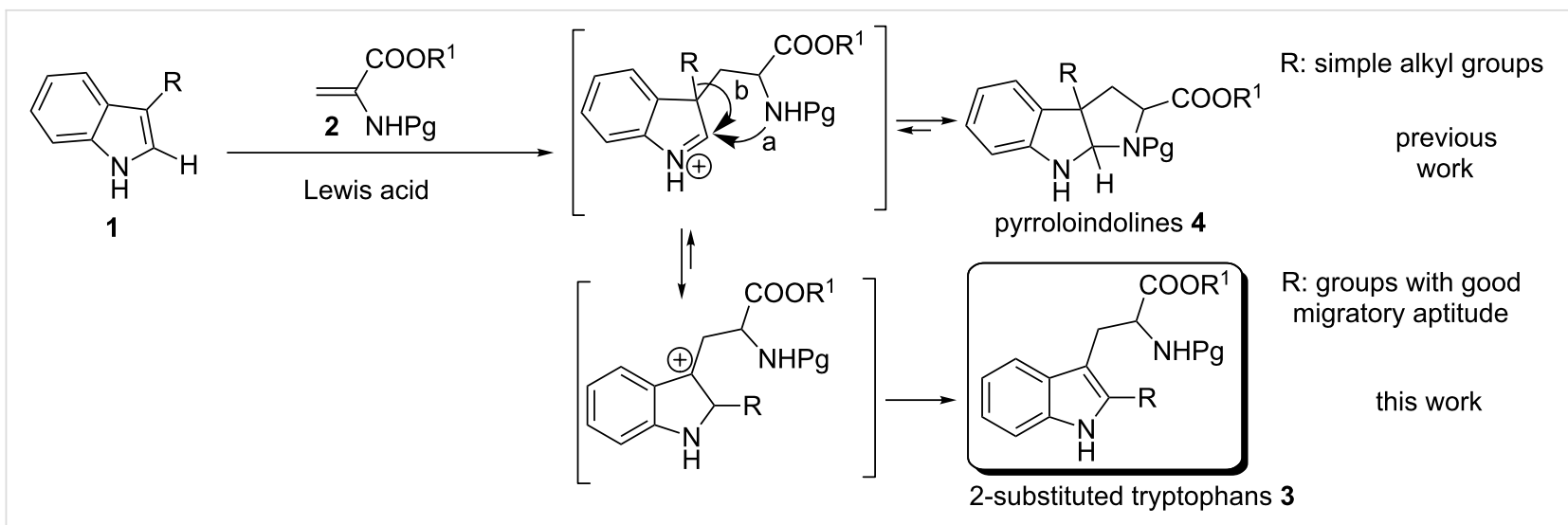

Scheme 1: Friedel-Crafts alkylation of 3-substituted indoles.

observed. A plausible mechanism for the formation of this unexpected side product involves rearrangement of pyrroloindoline 4 to the corresponding 2-substituted tryptophan 3 by a C3to $\mathrm{C} 2$-alkyl indole migration and rearomatization (Scheme 1 , path $\mathrm{b}$ ). Therefore, the aim of this study was to exploit the $\mathrm{C} 3$ Friedel-Crafts (FC) alkylation/C3- to $\mathrm{C} 2$ alkyl migration sequence for the synthesis of 2-substituted tryptophans [45-50].

The known methods for the synthesis of 2-substituted tryptophans are limited and include both the catalytic and noncatalytic union of 2-alkylindole with a protected aziridine-2carboxylate or an $\alpha$-aminoenoate [38,51-54] or directly from 2 -unsubstituted protected tryptophan and the appropriate nucleophiles via a 3-chloroindolenine intermediate [55-57]. More recently, direct C2-arylation and alkylation of $\mathrm{N}$-protected tryptophan methyl ester have been reported in the context of a more extensive study on $\mathrm{C}-\mathrm{H}$ activation reactions [58-61]. The present procedure is comparable to those described previously in terms of yield, but it is superior to previous methods with respect to its simplicity as it employs easily accessible 3 -substituted indoles.

\section{Results and Discussion}

Initially, the optimal conditions for the critical alkylative dearomatization-cyclization followed by the migration/rearomatization reaction process were explored. Our initial attempt involved reacting readily available 3-benzylindole (1a) with commercially available $\mathrm{N}$-acetyl-dehydroalanine methyl ester (2a) under the reaction conditions previously optimized for the synthesis of pyrroloindolines. However, in the presence of $\mathrm{ZrCl}_{4}$ (2 equiv), the reaction gave a low conversion (Table 1, entry 1).

It was found that the non-coordinating solvent $\mathrm{CH}_{2} \mathrm{Cl}_{2}$ gave the best results whereas moving to more polar solvents such as ethanol, DMF, and THF proved to be detrimental, presumably due to coordination to the Lewis acid (Table 1, entries 2-4). The use of a strong H-bond donor such as trifluoroethanol (TFE) did not accelerate the reaction and still gave low yields after $24 \mathrm{~h}$ (Table 1, entry 5). Next, we tested the effect of different acids on the reaction. Although some Lewis acids such as $\mathrm{TiCl}_{4}, \mathrm{SnCl}_{4}$, and $\mathrm{Sc}(\mathrm{OTf})_{3}$ did not show beneficial effects (Table 1, entries 6-8), a good yield of 2-benzyltryptophan was achieved when 2 equiv of $\mathrm{EtAlCl}_{2}$ was used (Table 1, entry 9). Notably, resubmission of isolated pyrroloindoline $\mathbf{4 a}$, obtained by reducing the reaction time to five hours (Table 1, entry 12), to the exact reaction conditions above, provided another batch of 2-benzyltryptophan (3a), showing that pyrroloindoline is the intermediate of the reaction. However, increasing the amount of acid did not afford a higher yield (Table 1, entry 11); but on the contrary, a smaller amount prevented the reaction from going to completion (Table 1, entry 10). Despite research by Jackson et al. [45-50] showing an intramolecular rearrangement to yield 2,3-disubstituted indoles using TFA or diluted $\mathrm{HCl}$, our synthetic procedure did not work with the addition of these acids, and only some indole oligomers were obtained. The best yield and reactivity were obtained by conducting the reaction with 2 equiv of $\mathrm{EtAlCl}_{2}$ in $\mathrm{CH}_{2} \mathrm{Cl}_{2}$ at room temperature for 24 hours (Table 1, entry 9).

Under the optimized reaction conditions (Table 1, entry 9), the substrate scope was then examined, focusing on the relative migratory aptitudes of various $\mathrm{C} 3$-indole substituents; the results are summarized in Table 2 . The reaction worked well, affording good to excellent yields using 3-( $p$-methoxybenzyl)indole (1b) and 3-( $p$-chlorobenzyl)indole (1c), whereas it did not afford the desired 2-substituted tryptophan when 3-( $p$ nitrobenzyl)indole (1d) was used as the starting material. These results can be attributed to the greater migratory aptitude of both the $p$-methoxy- and $p$-chlorobenzyl groups, compared to the $p$-nitrobenzyl substituent (even though in this case a detrimental coordination between nitro group and Lewis acid can 
Table 1: Optimization of the reaction conditions. ${ }^{\text {a }}$<smiles>c1ccc(Cc2c[nH]c3ccccc23)cc1</smiles>

$1 a$ $+=\overbrace{\text { CoOMe }}^{\text {NHCOMe }} \frac{\text { Lewis acid }}{\text { solvent, } r \text { t, } 24 \mathrm{~h}}$

$2 a$

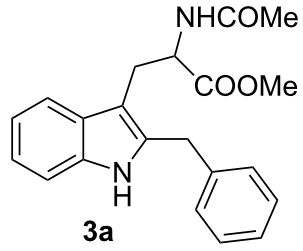

$3 a$

\begin{tabular}{llll}
\hline Entry & Lewis acid & Solvent & Yield $(\%)^{\mathrm{b}}$ \\
\hline 1 & $\mathrm{ZrCl}_{4}$ & $\mathrm{CH}_{2} \mathrm{Cl}_{2}$ & 25 \\
2 & $\mathrm{ZrCl}_{4}$ & $\mathrm{EtOH}$ & $\mathrm{NR}$ \\
3 & $\mathrm{ZrCl}_{4}$ & $\mathrm{DMF}$ & $\mathrm{NR}$ \\
4 & $\mathrm{ZrCl}_{4}$ & $\mathrm{THF}$ & $\mathrm{NR}$ \\
5 & $\mathrm{ZrCl}_{4}$ & $\mathrm{TFE}$ & 13 \\
6 & $\mathrm{TiCl}_{4}$ & $\mathrm{CH}_{2} \mathrm{Cl}_{2}$ & 15 \\
7 & $\mathrm{SnCl}_{4}$ & $\mathrm{CH}_{2} \mathrm{Cl}_{2}$ & 28 \\
8 & ${\mathrm{Sc}(\mathrm{OTf})_{3}}^{\mathrm{EtAlCl}}$ & $\mathrm{CH}_{2} \mathrm{Cl}_{2}$ & 12 \\
9 & $\mathrm{EtAlCl}_{2}$ & $\mathrm{CH}_{2} \mathrm{Cl}_{2}$ & 70 \\
$10^{\mathrm{c}}$ & $\mathrm{CtAlCl}_{2}$ & $\mathrm{CH}_{2} \mathrm{Cl}_{2}$ & 29 \\
$11^{\mathrm{d}}$ & $\mathrm{CH}_{2} \mathrm{Cl}_{2}$ & 68 \\
$12^{\mathrm{e}}$ & $\mathrm{EtAlCl}_{2}$ & $\mathrm{CH}_{2} \mathrm{Cl}_{2}$ & 25 \\
\hline
\end{tabular}

aReaction conditions: $1 \mathrm{a}(0.25 \mathrm{mmol}), \mathbf{2 a}(0.3 \mathrm{mmol})$, Lewis acid $(0.5 \mathrm{mmol})$, solvent $(2.5 \mathrm{~mL}), \mathrm{rt}, 24 \mathrm{~h}$. bYields of the isolated products after column chromatography. ' Lewis acid $(0.25 \mathrm{mmol})$. ${ }^{\mathrm{d} L e w i s}$ acid $(1 \mathrm{mmol})$. ${ }^{\mathrm{e}}$ The reaction was quenched after 5 hours to isolate the pyrroloindolines $4 \mathrm{a}$, see Supporting Information File 1 . NR, no reaction.

Table 2: Synthesis of 2-benzyltryptophans $\mathbf{3 a - j} .^{a}$

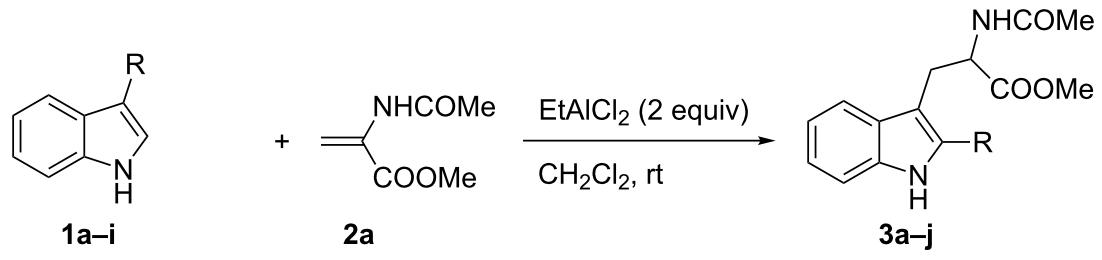

\begin{tabular}{|c|c|c|c|c|}
\hline Entry & Indole & Tryptophan & Time (h) & Yield $(\%)^{b}$ \\
\hline 1 & $\begin{array}{l}\dot{\mathrm{H}} \\
1 \mathrm{a}\end{array}$ & $3 a$ & 24 & 70 \\
\hline 2 & $1 b$ & $3 b$ & 16 & 74 \\
\hline
\end{tabular}


Table 2: Synthesis of 2-benzyltryptophans $\mathbf{3 a - j} .^{a}$ (continued)

3

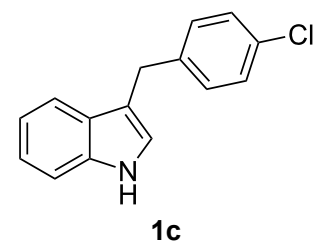

4

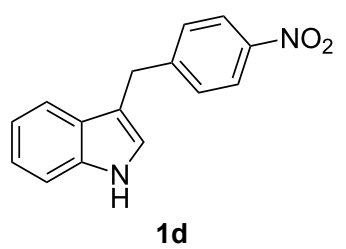

5

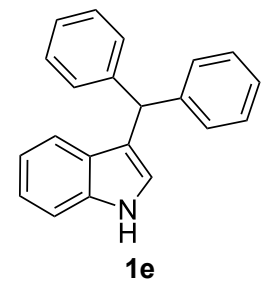

6<smiles>c1ccc2c(c1)CCCC2c1c[nH]c2ccccc12</smiles>

7

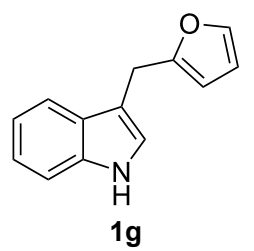

8

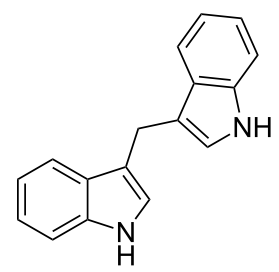

$1 \mathrm{~h}$

9

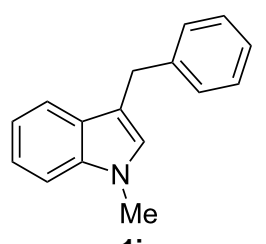

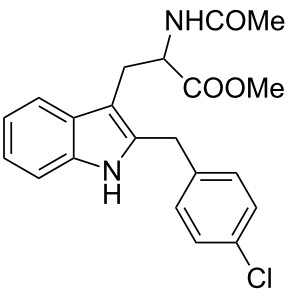

3c

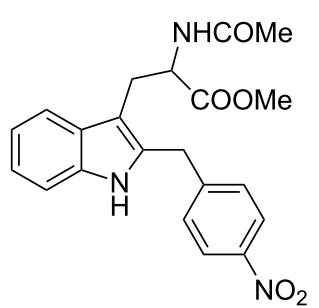

$3 d$
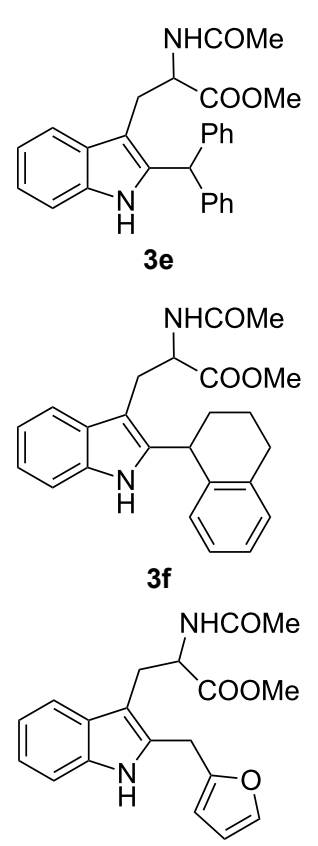

$3 g$

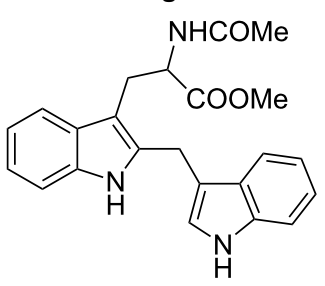

$3 h$

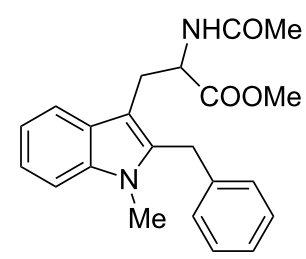

$3 \mathbf{3}$
48 53

72 NR

72 NR

72 11

72 NR

24 67

48 51 
Table 2: Synthesis of 2-benzyltryptophans $3 \mathbf{a}-\mathbf{j} .{ }^{a}$ (continued)

$10^{c}$

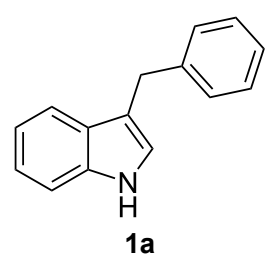

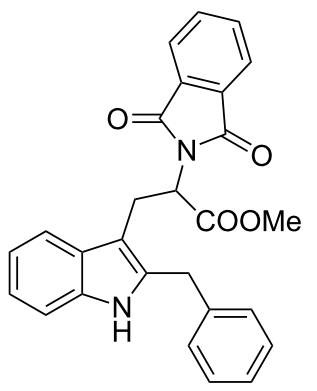

3j
24

48

aReaction Conditions: $1 \mathrm{a}-\mathbf{i}(0.25 \mathrm{mmol}), \mathbf{2 a}(0.3 \mathrm{mmol}), \mathrm{EtAlCl}_{2}(0.5 \mathrm{mmol}), \mathrm{CH}_{2} \mathrm{Cl}_{2}(2.5 \mathrm{~mL})$, rt. bYields of the isolated products after column chromatography. ${ }^{\mathrm{C}}$ Methyl 2-phthalimidoacrylate (2b) was used. NR, no reaction.

occur), thus agreeing with earlier studies on the benzylation of indoles [46].

Whereas indoles bearing a simple C3-benzyl substituent furnish products in good yields, the reaction is very sensitive to the steric bulk around the electrophilic alkyl carbon atom; this observation is in agreement with the fact that the C3-alkyl group is very likely to attack the electrophilic iminium species generated in situ after the Dha/Friedel-Crafts-type reaction with indoles. Attempts to carry out the alkylation/migration reaction with 3-benzhydrylindole (1e) were unfruitful (Table 2, entry 5). When 3-(tetrahydronaphthalen-1-yl)indole (1f) was used, a very low conversion to the corresponding 2-substituted tryptophan was observed (Table 2, entry 6). For indoles containing 3 -heterobenzyl substituents, the results were conflicting. Whereas 3-(furan-2-ylmethyl)indole (1g) did not react under the usual reaction conditions (Table 2, entry 7), bis(indol-3yl)methane (1h) provided the desired product in an excellent yield and decent time (Table 2 , entry 8 ). The latter is an interesting compound, and to the best of our knowledge, it has never been synthesized previously but only reported as a contaminant in biotechnologically manufactured tryptophan [62,63]. Also 3-benzyl- $N$-methylindole (1i) performed well in the reaction although a longer reaction time is needed to obtain a reasonable yield of the desired $\mathbf{3 i}$ (Table 2, entry 9). Regarding on the influence of the amine protecting group of Dha, the $\mathrm{N}$-acetyl protecting group might promote the $\mathrm{C} 3-\mathrm{C} 2$ rearrangement, rendering the intermediate 3,3-disubstituted indolenium salt more likely to accept the migrating alkyl group at the C2-position that is in equilibrium with the corresponding tricyclic pyrroloindolines. Indeed, the reaction between 3-benzylindole (1a) and methyl 2-phthalimidoacrylate (2b) gave only $48 \%$ yield of the desired rearranged product ( $\mathbf{3} \mathbf{j}$ ) (Table 2, entry 10) whereas the $N$-Cbz and $N$-Boc protecting groups were unstable under the reaction conditions.

As shown in Table 3, this novel reaction with Dha 2a is not restricted to 3-benzylindole derivatives but can also be

Table 3: Synthesis of 2-allyltryptophans $3 \mathbf{k}-\mathbf{o .}^{\text {a }}$

(n)


Table 3: Synthesis of 2-allyltryptophans $3 \mathbf{k}-\mathbf{0} .^{\text {a }}$ (continued)

2<smiles>CC(C)=CCc1c[nH]c2ccccc12</smiles>

3<smiles>CC(C)=CCC/C(C)=C/Cc1c[nH]c2ccccc12</smiles>

$1 \mathrm{~m}$

4<smiles>C=CC(C)(C)c1c[nH]c2ccccc12</smiles>

$1 n$

5<smiles>CSc1c[nH]c2ccccc12</smiles>

10<smiles>COC(=O)C(Cc1c(CC=C(C)C)[nH]c2ccccc12)NC(C)=O</smiles>

3I<smiles>CC(=O)NC(Cc1c(C/C=C(\C)CCC=C(C)C)[nH]c2ccccc12)C(C)=O</smiles>

$3 m$<smiles>C=CC(C)(C)c1[nH]c2ccccc2c1CC(NC(C)=O)C(C)=O</smiles>

aReaction conditions: $1 \mathrm{k}-\mathbf{o}(0.25 \mathrm{mmol}), 2 \mathrm{a}(0.3 \mathrm{mmol}), \mathrm{EtAlCl}_{2}(0.5 \mathrm{mmol}), \mathrm{CH}_{2} \mathrm{Cl}_{2}(2.5 \mathrm{~mL})$, rt. bYields of the isolated products after column chromatography. NR, no reaction.

employed for other types of $\mathrm{S}_{\mathrm{N}} 1$-active substrates such as 3-allylindoles [64]. Under the optimized conditions, the use of 3-allyl, 3,3-dimethylallyl ("normal" prenyl), and 3-geranylindoles as nucleophiles provided the corresponding 2-allyltryptophans [65] in good yields, after the expected C3- to C2-indole allyl migration (Table 3, entries 1-3). The high yielding synthesis of these compounds is of particular interest as 2-prenyltryptophan derivatives have been obtained or isolated from a diverse array of natural sources $[66,67]$ and, in general, prenylation at the indole ring leads to a significant increase in the antioxidant and/or cytotoxic activity of tryptophan-containing molecules [68-70]. However, the reaction did not occur with the indole bearing the more bulky 1,1-dimethylallyl ("reverse" prenyl) substituent at $\mathrm{C} 3$, confirming the limit of steric hindrance in this reaction (Table 3, entry 4). Unfortunately, the reaction with 3-propargylindole only afforded the corresponding pyrrolindoline derivative without any trace of the rearranged 2-substituted tryptophan, even with extended reaction times.
The electronic properties of the migratory group have a pronounced effect on the reaction profile. As known from other Wagner-Meerwein-type rearrangements [71], the migration tendency is principally controlled by the stability of the migratory cation. However, we reasoned that indoles with an electron-rich and polarizable atom/functional group at the C3-position (i.e., 3 -sulfenylindoles) could be good substrates for the reaction. Notably, 3-(methylthio)indole (10) underwent the alkylation/ C3-C2 migration sequence to give 2-(methylthio)tryptophan 30 in good yields (Table 3 , entry 5). Remarkably, the presence of a thioether in the indole ring offers unique, site-specific handles that can be utilized for further functionalization of the tryptophan moiety.

\section{Conclusion}

In summary, we have developed the synthesis of 2-functionalized/substituted tryptophans through a novel alkylative dearomatization-cyclization/migration/rearomatization sequence between easily accessible 3 -substituted indoles and commer- 
cially available Dha 2a for the construction of 2-substituted tryptophans. The final rearrangement proceeded in moderate to very good yields, depending on the migration tendencies of the $\mathrm{C} 3$-indole substituent. Although the substituent migration from the C3- to C2-indole position is principally limited to benzyl, allyl/prenyl, and sulfenyl groups, the operational simplicity, synthetic brevity, and relatively facile access to 3 -substituted indoles should make it very useful for the preparation of C2-functionalized tryptophan derivatives.

\section{Experimental}

\section{General procedure for the synthesis of} $\mathrm{N}$-acetyl-2-substituted tryptophan methyl ester

A $1 \mathrm{M}$ solution of $\mathrm{EtAlCl}_{2}$ in hexane $(2 \mathrm{mmol}, 2 \mathrm{~mL})$ was added dropwise to a stirred and cooled $\left(0^{\circ} \mathrm{C}\right)$ mixture of methyl 2-acetamidoacrylate $(172 \mathrm{mg}, 1.2 \mathrm{mmol})$ and the suitable 3-substituted indole $(1 \mathrm{mmol})$ in dry $\mathrm{CH}_{2} \mathrm{Cl}_{2}(10 \mathrm{~mL})$ under a nitrogen atmosphere. The mixture was stirred at room temperature for 17-72 hours, then carefully poured into an ice-cold saturated aqueous sodium hydrogen carbonate solution $(10 \mathrm{~mL})$. The resulting suspension was filtered through Celite and the aqueous layer was extracted with dichloromethane $(3 \times 15 \mathrm{~mL})$. The combined organic layers were dried over sodium sulfate, filtered and concentrated in vacuo. The crude product was purified by flash chromatography on silica gel (cyclohexane/ethyl acetate 8:2, or $\mathrm{CH}_{2} \mathrm{Cl}_{2} /$ methanol 98:2 for $\mathbf{3 h}$, as eluent) and/or crystallization.

\section{Supporting Information}

\section{Supporting Information File 1}

Experimental procedures, characterization data, ${ }^{1} \mathrm{H}$ and

${ }^{13} \mathrm{C}$ NMR spectra of new compounds.

[http://www.beilstein-journals.org/bjoc/content/ supplementary/1860-5397-10-207-S1.pdf]

\section{Acknowledgements}

We gratefully acknowledge the financial support of the University of Urbino "Carlo Bo", and the PhD Programs of Ministry of Education of Italy.

\section{References}

1. Liu, Q.; Zhang, Y.-A.; Xu, P.; Jia, Y. J. Org. Chem. 2013, 78, 10885-10893. doi:10.1021/jo4018777

2. Zhang, Y.-A.; Liu, Q.; Wang, C.; Jia, Y. Org. Lett. 2013, 15, 3662-3665. doi:10.1021/ol401541t

3. Lesma, G.; Cecchi, R.; Cagnotto, A.; Gobbi, M.; Meneghetti, F.; Musolino, M.; Sacchetti, A.; Silvani, A. J. Org. Chem. 2013, 78, 2600-2610. doi:10.1021/jo302737j
4. Okamoto, K.; Sakagami, M.; Feng, F.; Togame, H.; Takemoto, H.; Ichikawa, S.; Matsuda, A. J. Org. Chem. 2012, 77, 1367-1377. doi:10.1021/jo202159q

5. Zhao, L.; May, J. P.; Huang, J.; Perrin, D. M. Org. Lett. 2012, 14, 90-93. doi:10.1021/ol202880y

6. Kim, J.; Movassaghi, M. J. Am. Chem. Soc. 2011, 133, 14940-14943. doi:10.1021/ja206743v

7. Movassaghi, M.; Ahmad, O. K.; Lathrop, S. P. J. Am. Chem. Soc. 2011, 133, 13002-13005. doi:10.1021/ja2057852

8. Davey, N. E.; Van Roey, K.; Weatheritt, R. J.; Toedt, G.; Uyar, B.; Altenberg, B.; Budd, A.; Diella, F.; Dinkel, H.; Gibson, T. J. Mol. BioSyst. 2012, 8, 268-281. doi:10.1039/c1mb05231d

9. de Sa Alves, F. R.; Barreiro, E. J.; Manssour Fraga, C. A. Mini-Rev. Med. Chem. 2009, 9, 782-793. doi:10.2174/138955709788452649

10. Royer, C. A. Chem. Rev. 2006, 106, 1769-1784. doi:10.1021/cr0404390

11. Heringa, J.; Argos, P. J. Mol. Biol. 1991, 220, 151-171. doi:10.1016/0022-2836(91)90388-M

12. Kielkopf, C. L.; Lücke, S.; Green, M. R. Genes Dev. 2004, 18, 1513-1526. doi:10.1101/gad.1206204

13. Corsini, L.; Bonnal, S.; Basquin, J.; Hothorn, M.; Scheffzek, K.; Valcárcel, J.; Sattler, M. Nat. Struct. Mol. Biol. 2007, 14, 620-629. doi:10.1038/nsmb1260

14. Neufeld, C.; Filipp, F. V.; Simon, B.; Neuhaus, A.; Schüller, N.; David, C.; Kooshapur, H.; Madl, T.; Erdmann, R.; Schliebs, W.; Wilmanns, M.; Sattler, M. EMBO J. 2009, 28, 745-754. doi:10.1038/emboj.2009.7

15. Lepthien, S.; Hoesl, M. G.; Merkel, L.; Budisa, N. Proc. Natl. Acad. Sci. U. S. A. 2008, 105, 16095-16100. doi:10.1073/pnas.0802804105

16. Versées, W.; Loverix, S.; Vandemeulebroucke, A.; Geerlings, P.; Steyaert, J. J. Mol. Biol. 2004, 338, 1-6. doi:10.1016/j.jmb.2004.02.049

17. Callis, P. R. Methods Enzymol. 1997, 278, 113-150. doi:10.1016/S0076-6879(97)78009-1

18. Gademann, K.; Hintermann, T.; Scheiber, J. V. Curr. Med. Chem. 1999, 6, 905-925. And references cited therein

19. Cole, D. C. Tetrahedron 1994, 50, 9517-9582. doi:10.1016/S0040-4020(01)85527-7

20. Ojima, I.; Lin, S.; Wang, T. Curr. Med. Chem. 1999, 6, 927-954.

21. Fülöp, F. Chem. Rev. 2001, 101, 2181-2204. doi:10.1021/cr000456z

22. Forro, E.; Fülöp, F. Mini-Rev. Org. Chem. 2004, 1, 93-102. doi:10.2174/1570193043488908

23. Lelais, G.; Seebach, D. Biopolymers 2004, 76, 206-243. doi:10.1002/bip.20088

24. Kuhl, A.; Hahn, M. G.; Dumić, M.; Mittendorf, J. Amino Acids 2005, 29 , 89-100. doi:10.1007/s00726-005-0212-y

25. Lukaszuk, A.; Demaegdt, H.; Szemenyei, E.; Tóth, G.; Tymecka, D.; Misicka, A.; Karoyan, P.; Vanderheyden, P.; Vauquelin, G.; Tourwé, D. J. Med. Chem. 2008, 51, 2291-2296. doi:10.1021/jm701490g

26. Aydillo, C.; Compañón, I.; Avenoza, A.; Busto, J. H.; Corzana, F.; Peregrina, J. M.; Zurbano, M. M. J. Am. Chem. Soc. 2014, 136, 789-800. doi:10.1021/ja411522f

27. Pirovano, V.; Facoetti, D.; Dell'Acqua, M.; Della Fontana, E.; Abbiati, G.; Rossi, E. Org. Lett. 2013, 15, 3812-3815. doi:10.1021/ol401716b

28. Wang, Z.; Luo, S.; Zhang, S.; Yang, W.-L.; Liu, Y.-Z.; Li, H.; Luo, X.; Deng, W.-P. Chem. - Eur. J. 2013, 19, 6739-6745. doi:10.1002/chem.201300204 
29. Attanasi, O. A.; Favi, G.; Giorgi, G.; Mantellini, F.; Moscatelli, G.; Piersanti, G. Curr. Org. Synth. 2013, 10, 803-811. doi:10.2174/1570179411310050011

30. Jousseaume, T.; Wurz, N. E.; Glorius, F. Angew. Chem., Int. Ed. 2011, 50, 1410-1414. doi:10.1002/anie.201006548

31. Duan, S.-W.; An, J.; Chen, J.-R.; Xiao, W.-J. Org. Lett. 2011, 13, 2290-2293. doi:10.1021/ol200550y

32. Repka, L. M.; Ni, J.; Reisman, S. E. J. Am. Chem. Soc. 2010, 132, 14418-14420. doi:10.1021/ja107328g

33. Huestis, M. P.; Chan, L.; Stuart, D. R.; Fagnou, K. Angew. Chem., Int. Ed. 2011, 50, 1338-1341. doi:10.1002/anie.201006381

34. Wieland, J.; Breit, B. Nat. Chem. 2010, 2, 832-837. doi:10.1038/nchem. 800

35. Gilmore, C. D.; Allan, K. M.; Stoltz, B. M. J. Am. Chem. Soc. 2008, 130, 1558-1559. doi:10.1021/ja0780582

36. Navarre, L.; Martinez, R.; Genet, J.-P.; Darses, S. J. Am. Chem. Soc 2008, 130, 6159-6169. doi:10.1021/ja710691p

37. Chapman, C. J.; Hargrave, J. D.; Bish, G.; Frost, C. G. Tetrahedron 2008, 64, 9528-9539. doi:10.1016/j.tet.2008.07.067

38. Angelini, E.; Balsamini, C.; Bartoccini, F.; Lucarini, S.; Piersanti, G. J. Org. Chem. 2008, 73, 5654-5657. doi:10.1021/jo800881u

39. Lucarini, S.; Bartoccini, F.; Battistoni, F.; Diamantini, G.; Piersanti, G.; Righi, M.; Spadoni, G. Org. Lett. 2010, 12, 3844-3847. doi:10.1021/ol101527j

40. Righi, M.; Bartoccini, F.; Lucarini, S.; Piersanti, G. Tetrahedron 2011, 67, 7923-7928. doi:10.1016/j.tet.2011.08.039

41. Bartolucci, S.; Bartoccini, F.; Righi, M.; Piersanti, G. Org. Lett. 2012, 14, 600-603. doi:10.1021/ol203216h

42. Lucarini, S.; Mari, M.; Piersanti, G.; Spadoni, G. RSC Adv. 2013, 3, 19135-19143. doi:10.1039/c3ra42922a

43. Mari, M.; Bartoccini, F.; Piersanti, G. J. Org. Chem. 2013, 78, 7727-7734. doi:10.1021/jo4013767

44. Bartoccini, F.; Casoli, M.; Mari, M.; Piersanti, G. J. Org. Chem. 2014, 79, 3255-3259. doi:10.1021/jo500245s

45. Jackson, A. H.; Smith, A. E. Tetrahedron 1965, 21, 989-1000. doi:10.1016/0040-4020(65)80038-2

46. Jackson, A. H.; Smith, A. E. Tetrahedron 1968, 24, 403-413. doi:10.1016/0040-4020(68)89038-6

47. Jackson, A. H.; Smith, P. Tetrahedron 1968, 24, 2227-2239. doi:10.1016/0040-4020(68)88125-6

48. Jackson, A. H.; Naidoo, B.; Smith, P. Tetrahedron 1968, 24, 6119-6129. doi:10.1016/S0040-4020(01)96344-6

49. Biswas, K. M.; Jackson, A. H. Tetrahedron 1969, 25, 227-241. doi:10.1016/S0040-4020(01)99475-X

50. Ibaceta-Lizana, J. S. L.; Jackson, A. H.; Prasitpan, N.; Shannon, P. V. R. J. Chem. Soc., Perkin Trans. 2 1987, 1221-1226. doi:10.1039/p29870001221

51. Li, J. P.; Newlander, K. A.; Yellin, T. O. Synthesis 1988, 73-76. doi:10.1055/s-1988-27471

52. Sui, Y.; Liu, L.; Zhao, J.-L.; Wang, D.; Chen, Y.-J. Tetrahedron Lett. 2007, 48, 3779-3782. doi:10.1016/j.tetlet.2007.04.002

53. Kieffer, M. E.; Repka, L. M.; Reisman, S. E. J. Am. Chem. Soc. 2012, 134, 5131-5137. doi:10.1021/ja209390d

54. Tirotta, I.; Fifer, N. L.; Eakins, J.; Hutton, C. A. Tetrahedron Lett. 2013, 54, 618-620. doi:10.1016/j.tetlet.2012.11.139

55. Depew, K. M.; Danishefsky, S. J.; Rosen, N.; Sepp-Lorenzino, L. J. Am. Chem. Soc. 1996, 118, 12463-12464. doi:10.1021/ja962954o

56. Kuehne, M. E.; Xu, F. J. Org. Chem. 1997, 62, 7950-7960. doi:10.1021/jo970207j
57. Schkeryantz, J. M.; Woo, J. C. G.; Siliphaivanh, P.; Depew, K. M.; Danishefsky, S. J. J. Am. Chem. Soc. 1999, 121, 11964-11975. doi:10.1021/ja9925249

58. Lee, D.-H.; Kwon, K.-H.; Yi, C. S. Science 2011, 333, 1613-1616. doi:10.1126/science.1208839

See for C2-benzylation.

59. Gui, J.; Zhou, Q.; Pan, C.-M.; Yabe, Y.; Burns, A. C.; Collins, M. R.; Ornelas, M. A.; Ishihara, Y.; Baran, P. S. J. Am. Chem. Soc. 2014, 136, 4853-4856. doi:10.1021/ja5007838

See for C2-methylation.

60. Preciado, S.; Mendive-Tapia, L.; Albericio, F.; Lavilla, R. J. Org. Chem. 2013, 78, 8129-8135. doi:10.1021/jo400961x See for C2-arylation.

61. Potukuchi, H. K.; Bach, T. J. Org. Chem. 2013, 78, 12263-12267. doi:10.1021/jo402107m See for C2-alkylation.

62. Oguri, E. R. Identification and quantitative determination of major chemical contaminants associated with L-Tryptophan. U.S. Patent 12,347,892, Nov 22, 2011.

63. Simat, T. J.; Kleeberg, K. K.; Mueller, B.; Sierts, A. Eur. Food Res. Technol. 2003, 216, 241-252.

64. Wang, H.; Reisman, S. E. Angew. Chem., Int. Ed. 2014, 53 , 6206-6210. doi:10.1002/anie.201402571

A C3-C2 allyl rearrangement was noted recently during the synthesis of nocardioazin.

65. Okada, M. I.; Sato, I.; Cho, S. J.; Suzuki, Y.; Ojika, M.; Dubnau, D.; Sakagami, Y. Biosci., Biotechnol., Biochem. 2004, 68, 2374-2387. doi:10.1271/bbb.68.2374

66. Williams, R. M.; Stocking, E. M.; Sanz-Cervera, J. F. Top. Curr. Chem. 2000, 209, 97-173. doi:10.1007/3-540-48146-X_3

67. Li, S.-M. Nat. Prod. Rep. 2010, 27, 57-78. doi:10.1039/b909987p

68. Wollinsky, B.; Ludwig, L.; Hamacher, A.; Yu, X.; Kassack, M. U.; Li, S.-M. Bioorg. Med. Chem. Lett. 2012, 22, 3866-3869. doi:10.1016/j.bmcl.2012.04.119

69. Rudolf, J. D.; Wang, H.; Poulter, C. D. J. Am. Chem. Soc. 2013, 135, 1895-1902. doi:10.1021/ja310734n

70. Botta, B.; Vitali, A.; Menendez, P.; Misiti, D.; Delle Monache, G. Curr. Med. Chem. 2005, 12, 713-739. doi:10.2174/0929867053202241

71. Birladeanu, L. J. Chem. Educ. 2000, 77, 858-863. doi:10.1021/ed077p858

\section{License and Terms}

This is an Open Access article under the terms of the Creative Commons Attribution License (http://creativecommons.org/licenses/by/2.0), which permits unrestricted use, distribution, and reproduction in any medium, provided the original work is properly cited.

The license is subject to the Beilstein Journal of Organic Chemistry terms and conditions: (http://www.beilstein-journals.org/bjoc)

The definitive version of this article is the electronic one which can be found at: doi:10.3762/bjoc. 10.207 